\title{
dossier
}

\section{El Colegio del Cercado de Lima al momento de la expulsión de la Compañía}

\author{
René Millar Carvacho \\ Pontificia Universidad Católica de Chile (Santiago, Chile) \\ rmillarc@uc.cl
}

\section{RESUMEN}

La ejecución de la orden de extrañamiento de los jesuitas de los dominios de la Corona española llevó aparejada la elaboración de inventarios de todos los bienes que poseían los diferentes colegios y residencias de la orden. A partir del inventario que se hizo del Colegio del Cercado de Lima intentamos representar las instalaciones que poseía al momento de la expulsión, mostrar el personal que lo ocupaba y las actividades que realizaban sus miembros. También se analizan, en su proyección temporal, algunos aspectos relacionados con la función misionera que cumplía el colegio. Por último, se presenta la situación patrimonial que poseía esta institución y el estado financiero a septiembre de 1767. 
Palabras clave: jesuitas, Lima, parroquias de indios, colegio, evangelización

The Colegio del Cercado de Lima at the time of the expulsion of the Jesuits

\begin{abstract}
The expulsion of the Jesuits from the domains of the Spanish Crown, was followed by the preparation of inventories listing all the assets of each of the different schools and residences owned by the Order. Taking the inventory that was made of the Colegio del Cercado de Lima, we try to show the facilities it had at the time of the expulsion, the staff that occupied the premises, and the activities carried out by its members. We also analyze the temporary projection of certain aspects of the missionary function performed by the school. Finally, we review the patrimonial situation of this institution and its financial statement as of September 1767.
\end{abstract}

KEYwORDs: jesuits, Lima, Indian parish, school, evangelization

\title{
INTRODUCCIÓN
}

En el Archivo Nacional Histórico de Chile se encuentra un fondo relativamente poco trabajado, sobre todo considerando las posibilidades que brinda a los investigadores. Lo notable del caso es que no solo se refiere a Chile, sino que también a gran parte de los países de América, Filipinas y España. Se trata de documentación que perteneció a las Juntas de Temporalidades creadas por la Corona española a raíz de la expulsión de la Compañía de Jesús de los dominios hispanos y que, en su momento, se envió a Madrid. A lo largo del siglo XIX esos papeles en parte se dispersaron, circunstancia que llevó al gobierno de Chile, por recomendación de su diplomático Carlos Morla Vicuña, a adquirir, en 1877, las más de trece mil piezas que estaban en poder de Antonio Paz y Meliá, oficial de la Biblioteca Nacional de Madrid (Guia de Fondos del Archivo 
Nacional Histórico, 2009, p. 38; Soto Cárdenas, 1953, p. 146). En la actualidad, el fondo del Archivo Nacional Histórico se denomina «Junta de Temporalidades-Jesuitas de Chile y América» y en él se encuentra una sección Perú, que comprende setenta y cinco volúmenes. Entre esa documentación está el inventario de los bienes del colegio jesuita del Cercado, efectuado en 1767 para cumplir con el decreto de extrañamiento de la orden.

A partir de esa fuente, en este artículo intentamos reconstruir la situación del Colegio del Cercado al momento en que se produce el extrañamiento de la orden. ${ }^{1}$ Nos interesa acercarnos al conocimiento de su infraestructura, de la vida cotidiana de sus miembros, de las prácticas devocionales que se promocionaban desde su seno a la vista de los altares e imágenes de su templo, de la significación intelectual y religiosa que muestra el tipo de libros que guardaba su biblioteca; por último, tratamos de establecer cuál era su patrimonio y estado financiero al momento de la expulsión.

\section{La parroquia, la residencia y el Colegio del Príncipe}

A las cuatro de la madrugada del 9 de septiembre de 1767 los padres jesuitas que residían en el Colegio del Cercado de Lima fueron sacados abruptamente de sus aposentos por el oidor Gaspar Urquizu que, junto a funcionarios y tropa, procedió a ejecutar el decreto de extrañamiento de la Compañía de Jesús firmado por el Conde de Aranda. De esa manera se cerraba la historia de esa casa, que se había iniciado en el lejano año de 1570 con la creación del pueblo de Santiago del Cercado.

1 No nos referiremos al Colegio del Príncipe —o de hijos de caciques — que estableció en esa residencia el Príncipe de Esquilache en 1619. En el inventario hay escasa información sobre él y, además, existe una obra muy completa sobre el tema de Alaperrine-Bouyer (2007). Tampoco abordaremos el funcionamiento de las haciendas pertenecientes al colegio y a los esclavos con los que las explotaban. 
Es bastante conocido el proceso que llevó a la reducción de los indios del Perú en pueblos y, de manera específica, la que afectó a los de la ciudad de Lima, que fueron instalados en los arrabales de la parte oriental de la ciudad (Saito y Rosas Lauro, 2017; Coello de la Rosa, 2002, 2006; Cárdenas Ayaipoma, 1980; Rodríguez, 2005). Por decisión del virrey Toledo y con acuerdo del arzobispo Jerónimo de Loayza se entregó a los jesuitas el cuidado espiritual de los indios del nuevo poblado, ${ }^{2}$ que se denominó Santiago y debido a que fue rodeado de murallas también se le conoció como el Cercado. El poblado se dividió en treinta y cinco manzanas, con ciento veintidós solares en cada una (Coello de la Rosa, 2002) y al poco tiempo se edificó una casa e iglesia para los padres. ${ }^{3}$ La provincia, inicialmente, destinó de manera permanente a un sacerdote, que cumplía la labor de párroco, y a un hermano, que le auxiliaba ${ }^{4}$ y enseñaba la doctrina y a leer a los niños. ${ }^{5}$ Desde el punto de vista de la organización se le consideró una residencia dependiente del Colegio de Lima, el que en 1600 destinaba a ella dos padres y dos hermanos. ${ }^{6}$ La aceptación que hizo la provincia tanto de esa doctrina como de la de Juli generó en su momento bastante controversia en el seno de la Compañía, porque sacaba a los padres de sus colegios, para desempeñarse como curas de almas de manera permanente. ${ }^{7}$ El visitador Juan de la Plaza, en 1576, proponía que se abandonara, pero la congregación provincial celebrada en Lima ese mismo año acordó que esa parroquia fuese conservada, ${ }^{8}$ y lo propio hizo la de

2 Egaña (1954-1886 [MP], I, pp. 353, 375); Vargas Ugarte (1963, I, p. 65).

3 MP (I, p. 416, carta de Juan Gómez a Francisco de Borja, de comienzos de 1571).

$4 \quad$ MP (II, p. 136; III, p. 221, catálogo de la provincia del Perú de 1583).

$5 \mathrm{MP}$ (I, p. 416).

$6 \quad$ MP (II, p. 220; III, p. 221); Mateos (1943, I, p. 38).

7 MP (I, pp. 500, 543). La provincia también había aceptado la doctrina de Huarochirí, pero se dejó en 1572, ver Albó (1966, p. 276), Vargas Ugarte (1963, I, pp. 131-135).

8 MP (I, pp. 66, 67). 
1582. Prominentes padres de la provincia, como Juan de Atienza y José de Acosta, defendían la presencia de la orden por los beneficios espirituales que representaba para los indios y las ventajas que tenía para el aprendizaje de su lengua, lo que era determinante para el éxito del proceso misionero. ${ }^{9}$ Finalmente, en 1584 el general Claudio Aquaviva permitió que se retuviera dicha doctrina. ${ }^{10}$

Pocos años después, en 1590, el control de los jesuitas sobre la parroquia se vio cuestionado y nada menos que por el arzobispo de Lima, Toribio Alfonso de Mogrovejo. El episodio, que involucró a las máximas autoridades del virreinato, es bastante conocido y se originó en el traslado de los indios del barrio de San Lázaro, dispuesto por el virrey, García Hurtado de Mendoza, al pueblo del Cercado. Esta decisión dejaba de manifiesto los intereses contrapuestos del arzobispo, que buscaba controlar las doctrinas en manos de los regulares, y de los jesuitas, que defendían su independencia ante la autoridad episcopal y buscaban concentrar toda la población india de Lima en el Cercado. El arzobispo, fundado en que los indios de San Lázaro estaban bajo el cuidado espiritual de una parroquia allí levantada, hizo construir una en el Cercado, nombró párroco y señaló que los jesuitas no tenían ningún derecho a actuar como curas en ese pueblo. El conflicto escaló hasta la corte y la Santa Sede, en donde fue finalmente zanjado, de manera casi simultánea, a favor de la Compañía, en 1591.11

Como indicaba el padre José de Acosta, la doctrina, que además de la iglesia, contaba con una casa para alojar a cuatro personas, ${ }^{12}$ servía para que algunos estudiantes y padres fueran a

9 MP (III, pp. 394, 632). Albó (1966, pp. 277-278) sintetiza los pros y los contras que se esgrimieron para acoger o rechazar las doctrinas.

10 MP (III, p. 343).

11 Un análisis general del tema en Coello de la Rosa (2000, pp. 259-294; 2004, pp. 1-30) y Vargas Ugarte (1963, I, pp. 187-190).

12 MP (II, pp. 136, 220, carta Informe del visitador Juan de la Plaza, 12 de diciembre de 1576). Este padre, en ese mismo documento, estimaba en doscientas cincuenta las casas que estaban edificadas en el poblado. 
aprender la lengua de los indios y para el retiro de algún religioso mayor, ${ }^{13}$ a lo que se agregaba el que regularmente algunos padres fueran a colaborar con la prédica y administración de sacramentos a los indios. Hacia 1589 se había construido, en palabras del padre Juan de Atienza, «una muy buena iglesia, muy alegre y bien adornada de retablo y ornamentos de iglesia y sacristía». ${ }^{14}$ Además, se había levantado un hospital en el mismo sitio donde estaba la casa de los padres. Un cambio significativo se produjo en febrero de 1593 con el traslado del noviciado y casa de probación, que hasta ese momento había funcionado en el Colegio de San Pablo, a las casas que tenía la Compañía en el Cercado. El provincial Juan Sebastián de la Parra consideró que para la formación de los novicios era más conveniente que estuvieran alejados de las distracciones que existían en el centro de Lima. Siete años permaneció en ese sitio, hasta que se le trasladó a un edificio propio en unas tierras en el mismo Cercado, pero a orillas del río (Mateos, 1943, I, pp. 3, 389, 391). San José fue el nombre que se le dio al nuevo noviciado, el cual permaneció poco tiempo en esas instalaciones debido a que era una zona malsana, que afectó la salud de los novicios y obligó, a los tres años, a volver a las primitivas instalaciones en las casas parroquiales. ${ }^{15}$ Merced a una donación, se trasladó definitivamente a una zona cercana al centro de Lima, donde se construyó un gran edificio para albergarlo, ahora bajo el nombre de noviciado de San Antonio Abad.

Otra fundación importante que se realizó en la doctrina correspondió al colegio de hijos de caciques. Esta obra fue resultado

13 MP (III, p. 573).

14 MP (IV, p. 479). Una relación de la labor evangelizadora y de otras actividades que allí se realizaban en beneficio de la población, en Mateos (1943, I, pp. 230236). Sobre las dificultades que la cultura de los indios planteaba a la cristianización y las estrategias evangelizadoras que se utilizaron en el Cercado, ver Coello de la Rosa (2006, pp. 109-117). Una presentación sobre las políticas generales de evangelización de los jesuitas en Perú en Estenssoro Fuchs (2003, pp. 203-237).

15 MP (VIII, pp. 199-200, carta anua de 1602). Mateos (1943, I, pp. 32, 391). 
de la iniciativa del virrey príncipe de Esquilache, que hizo realidad en 1619 un proyecto que se debatía desde el siglo XVI. ${ }^{16}$ Se instaló en la casa que se destinaba a hospital, que estaba sin uso, y comenzó a funcionar con doce colegiales, con el nombre de Colegio del Príncipe (Puente Brunke, 1998, p. 463). ${ }^{17} \mathrm{Al}$ mismo tiempo, el virrey ordenó el establecimiento en el Cercado, también bajo la administración de los jesuitas, de una cárcel para los indios dogmatizadores y «ministros de idolatría», denominada de Santa Cruz (Esquilache, 1978, p. 193; Cobo, 1882, p. 141; Pallas, 2006, p. 214).

Un hito significativo en el desarrollo de la residencia correspondió al salto cuantitativo y cualitativo que experimentó, en 1640, a raíz de una importante donación de cincuenta mil pesos, que le permitió adquirir la hacienda de Vilcahuaura y que le proporcionó una renta para financiar la actividad misionera en la sierra de seis sacerdotes, que impuso como obligación el donante. De hecho, esta donación, al decir de varios testigos, incluidos dos exrectores, habría implicado la fundación del Colegio del Cercado, ${ }^{18}$ el cual «esté separado para siempre jamás de la casa grande de Lima y de otra casa cualquiera que tenga la Compañía en otra parte alguna». ${ }^{19}$ De

16 Una relación de todas las etapas por las que pasó el proceso de fundación y también del funcionamiento de los colegios de hijos de caciques de los que se encargó la Compañía, en Alaperrine-Bouyer (2007). Puente Brunke (1998) refiere las quejas de curacas por el mal funcionamiento del colegio.

17 El colegio se financiaba con el pago de una asignación anual que entregaba la caja general de censos, Archivo Nacional Histórico de Chile [ANHCh], Jesuitas de América, 410, cuaderno 4, f. 13.

18 ANHCh, Jesuitas de América, vol. 410, cuaderno 4, ff. 16 y ss. El donante fue Juan Clemente Fuentes y su testamento está en AHNCh, Jesuitas de América, vol. 410, cuaderno 4, ff. $19 \mathrm{v}-32$.

19 ANHCh, Jesuitas de América, vol. 410, cuaderno 4, f. 36v. Cláusula de una escritura de Juan Clemente Fuentes, para que constase a la Compañía y a su «generalísimo». 
ese modo, la residencia se habría transformado en colegio. ${ }^{20}$ Sin embargo, el cambio solo se oficializó en 1654, «en que por tener competente fundación comienza a ser colegio destinado a misiones, sin dejar la obligación que los sujetos del tienen de acudir a sus indios como sus curas». ${ }^{21}$

La última alteración que experimentó el Colegio del Cercado, que terminó por darle la fisonomía que mantuvo hasta el final, fue la instalación en sus dependencias, en abril de 1692, de la tercera probación, es decir, de un tercer año de noviciado, que se hacía con el propósito de alcanzar una renovación espiritual después de muchos años de estudio (Gramatowski, 1992, p. 23). Fue una determinación del general Tirso González que, en parte, señala: «La tercera probación se ha de poner sin falta en el Cercado, sacándola o quitándola de los colegios del Cuzco o Guamanga» (Torres Saldamando, 1882, p. 364).

\section{El ESPACiO Y LAS INSTALACIONES}

El Colegio del Cercado estaba ubicado en el costado sur poniente de la plaza en forma de rombo del pueblo de indios, cuya traza sería una representación de la Nueva Jerusalén, parecida a la que pintaba Martín de Vos, con calles orientadas según los puntos cardinales, altas murallas que la encerraban y puertas de acceso (Mattos-Cárdenas, 2004; Ríos Figueroa, 2014). La iglesia, con dos

20 En el léxico jesuita, «residencia» correspondía a la casa que no tenía el estatus de colegio, por lo que no entregaba formación escolar de segundo nivel.

21 Archivum Romanum Societatis Iesu, Perú 4, Catálogo del estado de la provincia, 1654, f. 499r. En ese año residían en él nueve sujetos, seis de ellos sacerdotes y los tres restantes hermanos coadjutores. En este catálogo también se señalaba que el colegio de caciques pertenecía al Colegio del Cercado y que había de ordinario de veinte a veinticuatro colegiales, hijos de caciques, a cuya enseñanza asistían dos de la Compañía, incluidos en los nueve antes indicados. 
pequeñas torres de madera, en mal estado, y su campanario, con cinco campanas, dominaba todo el pueblo. ${ }^{22}$ El colegio ocupaba una superficie total de 17,086 varas cuadradas, es decir, un poco menos de una hectárea y media, pero en esa extensión se incluía la huerta, que tenía 7,769 varas.

La información detallada sobre los edificios y su contenido se encuentra en el inventario que efectuó la comisión encargada de ejecutar el decreto de extrañamiento, en la que participaban - junto a los cargos superiores - tasadores, funcionarios de la casa de moneda y el maestro alarife Alonso Ribera, que fue el encargado de hacer la mensura y elaborar el plano que se adjuntó al inventario. ${ }^{23}$ La iglesia, parroquia del poblado, constituía el edificio de mayor tamaño del conjunto y su construcción era antigua, al decir de los peritos. Tenía 45 metros de largo por 14 de ancho y en el crucero alcanzaba los 18 metros.

22 ANHCh, Jesuitas de América, vol. 409, f. 208v. De acuerdo con el inventario, la iglesia tendría un campanario, ubicado sobre el lado derecho del transepto. A eso se agregarían dos torres de madera en el frontis del templo.

23 ANHCh, Jesuitas de América, vol. 409, cuaderno 2, f. 157r, 160r. AlaperrineBouyer (2007, p. 66) publicó el plano, pero indicaba desconocer el nombre de su autor y la fecha de elaboración. 


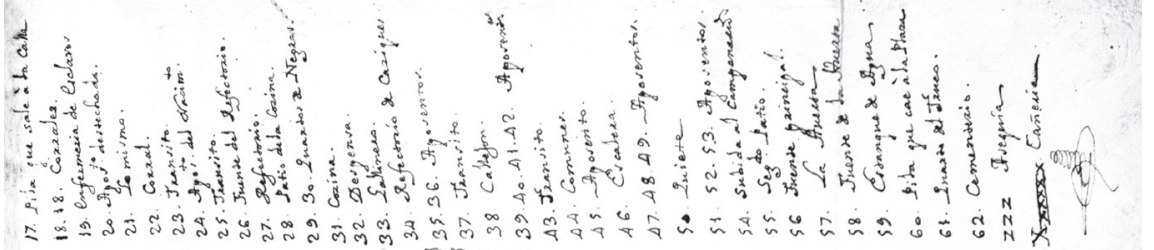

की

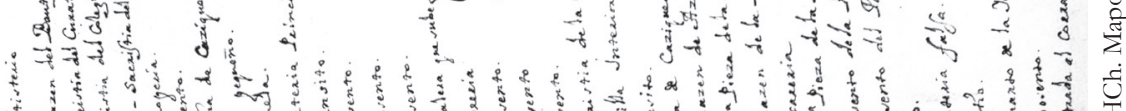

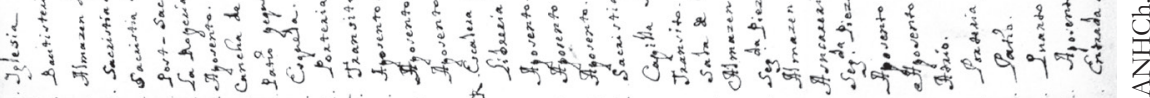

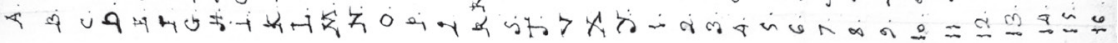

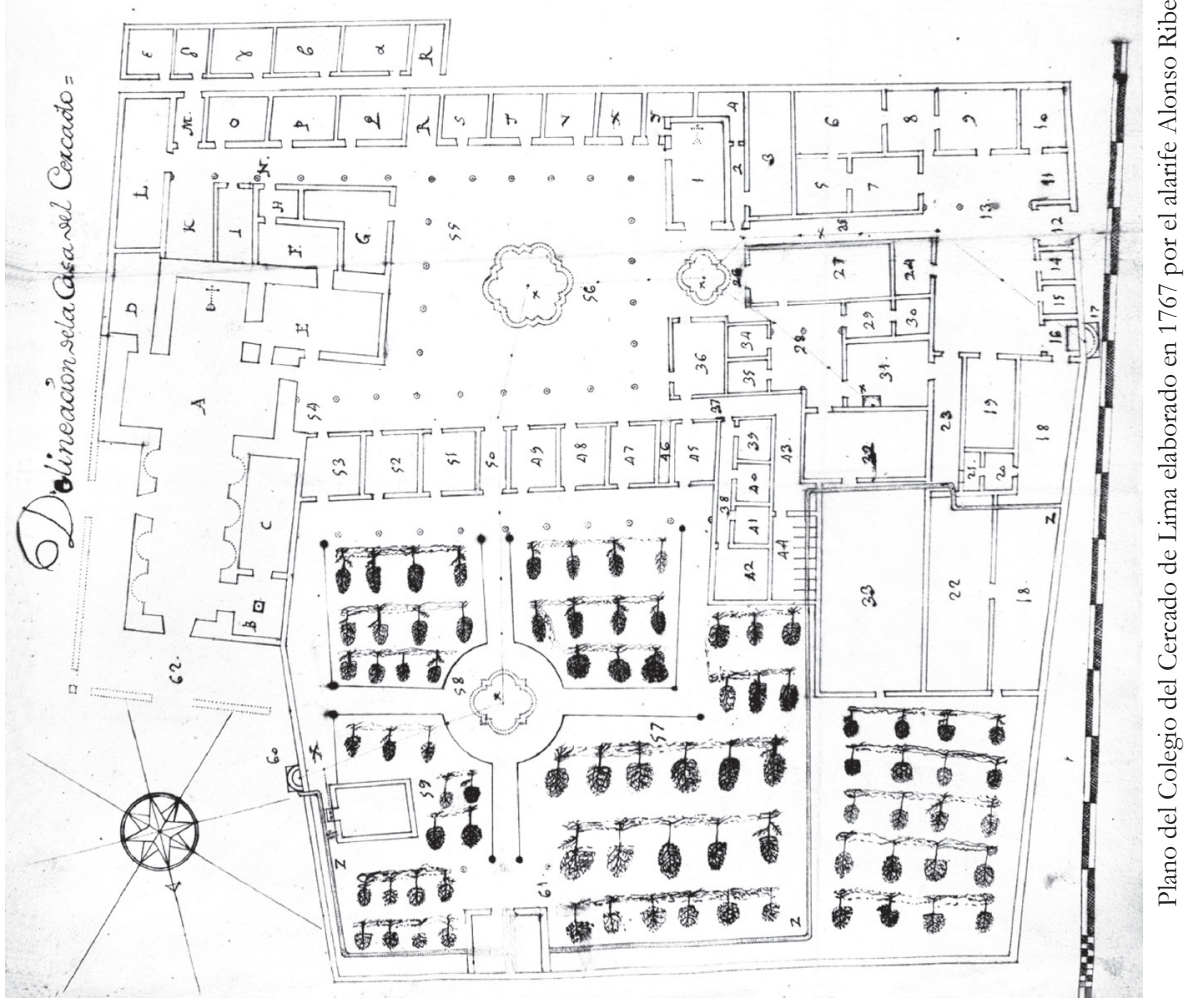


Delante de su entrada se encontraba un cementerio de reducidas dimensiones, que se extendía algunos metros por el costado izquierdo del edificio, donde había una entrada lateral al templo. Su planta era de forma latina y en su interior, entrando a mano derecha, estaba la capilla del baptisterio, a la que seguía un almacén. En la nave, tanto a izquierda como a derecha, había tres nichos por lado que albergaban sendos retablos. A un costado del altar mayor, por la parte del evangelio se encontraba la sacristía del curato y por el sector de la epístola se entraba a la sacristía del colegio, que era de gran tamaño y además poseía una habitación anexa. La planta del templo tenía alguna semejanza con la del noviciado de San Antonio Abad, la cual también poseía un cementerio, junto a su atrio (Mattos-Cárdenas, 2016, p. 30); algo similar encontramos en la iglesia del colegio de Huamanga, que también era de planta latina (Page, 2019, p. 30), ${ }^{24}$ lo que indica que ese tipo de templos responde, en parte, a una tipología que la Compañía utilizó con frecuencia en sus colegios.

La puerta principal de ingreso al colegio estaba por la calle que corría por el costado sur del establecimiento, al llegar a la esquina con la calle que lo limitaba por el oriente. Después de pasar un atrio, se ingresaba a un patio pequeño, a cuya derecha estaba la escuela de hijos de caciques, cuya sala tenía cerca de 21 metros de largo por un poco menos de 6 de ancho. Hacia la izquierda seguía un pasillo que, por un lado, daba acceso a la sala de juego de bolos de los hijos de los caciques y también a la postsacristía del colegio, por el otro había tres aposentos. El pasillo desembocaba en un claustro, de 35 metros por lado, con corredores sostenidos por pilares de madera. Este sector correspondía al centro neurálgico del colegio. En torno a él estaban los aposentos de los padres, la biblioteca, la capilla interior, con su sacristía, el refectorio de los padres y el área de recreación o quiete. En su vértice sur oriente había una

$24 \mathrm{Al}$ parecer, la iglesia primitiva del colegio de San Pablo de Lima también tenía una planta similar, ver San Cristóbal Sebastián (2011, p. 175). 
escala de acceso a un segundo piso donde se encontraban cinco aposentos, en dirección al oriente. En el centro del patio había una fuente de bronce, con una pileta de cal y ladrillo, y en su costado occidental, en su esquina izquierda, un pasillo en dirección poniente conducía a los baños o comunes en la leyenda del plano. En ese mismo lado del claustro, pasado el corredor, había otra fuente de agua, a cuyo costado quedaba la capilla interior de 15 metros de largo por un poco menos de 7 metros de ancho. Hacia el poniente de esta segunda fuente se encontraba el refectorio principal de los padres, que era bastante grande, pues tenía 17.5 metros de largo por 8 de ancho. A su izquierda había un pasillo corto que desembocaba en un patio al que se abría la cocina, la gran despensa, el refectorio y la enfermería de los hijos de los caciques y las habitaciones de los esclavos. Un segundo pasillo, por el otro lado del refectorio de los padres, llevaba a un patio más grande, que culminaba en la denominada portería falsa. Este sector poniente del edificio estaba destinado fundamentalmente a actividades de servicio. Desde ese patio también se podía acceder a la cocina, al aposento del portero, a la enfermería de los esclavos, al gallinero y a los corrales de las mulas, en los que había quince animales al realizarse el inventario.

Desde la parte central del claustro, por el norte, se ingresaba al quiete o zona de descanso de los padres, que además servía de entrada a la huerta, que tenía alrededor de 80 por 80 metros, la cual estaba dividida en cuarteles, con una fuente en su centro. Una pila que había junto al muro del colegio, en el costado de la plaza del pueblo, abastecía de agua a un estanque y a una acequia que rodeaba casi toda la huerta y, además, a una red de cañerías que proporcionaba agua a las fuentes del colegio y a una pila que estaba al costado de la puerta falsa, para uso público. El agua en la vida conventual de Lima no solo era importante como recurso para la vida, sino también para el espíritu, al acompañar, con su fluir, los momentos de meditación y quietud. En la huerta había plantada 
una variedad notable de frutales, en una muestra evidente de la fertilidad del valle de Lima, celebrada por los cronistas de la época. ${ }^{25}$

La distribución de los espacios del colegio, en general, respondía a la traza que tenían esas instituciones de la Compañía (Page, 2019 , p. 249). Se ubicaba en el lugar más destacado del pueblo, en su plaza. Poseía un área pública, que correspondía a la iglesia, y luego otra restringida a los padres, aunque en este caso su aislamiento era relativo, debido a que el colegio jesuita compartía espacios con el Colegio del Príncipe, lo que hacía que los religiosos convivieran con los hijos de caciques, que, en todo caso, en estos años, eran muy pocos, cuatro, según el inventario. ${ }^{26}$ Como se ha indicado, también existía un área de servicio, con los corrales, gallinero, dependencias de los esclavos, etc. Pero más allá de esos sectores, que se encontraban en casi todos los colegios de la Compañía, no es fácil visualizar otros elementos que permitan hablar de un tipo jesuítico de diseño arquitectónico. Esto se debía a que los establecimientos, incluso bajo una misma denominación, a veces cumplían funciones diferentes. Es lo que ocurre, por ejemplo, en los casos del Colegio de San Pablo y el Colegio del Cercado. Eso llevaba a que, a la hora de construir un establecimiento, se procurara responder a la función que cumpliría y al tipo de personas que lo ocuparía y utilizaría. Si revisamos algunos planos de colegios, como los de Huamanga y de Chuquisaca, es posible encontrar criterios similares, que también están en el Colegio del Cercado (Page, 2019, pp. 267-259). ¿Es ello suficiente para hablar de una tipología de diseño arquitectónico

25 ANHCh, Jesuitas de América, vol. 409, cuaderno 2, ff. 154v, 55r. En ella fueron inventariados, entre otros árboles, veintiún limoneros dulces y cuatro sutiles, cuarenta melocotones, treinta chirimoyos, cuatro de sidras, cuatro de manzanas, siete naranjos dulces y cuatro agrios, tres paltos, dos lúcumos, tres granados, dos higueras, un guayabo y veintiún parras.

26 Alaperrine-Bouyer (2007, p. 136) se refiere a la decadencia que había experimentado el Colegio del Príncipe en el siglo XVIII. 
jesuítico para los colegios? Tenemos dudas, pues muchos de esos elementos también están presentes en diversas obras de la arquitectura conventual del virreinato.

\section{RESIDENTES Y ACTIVIDADES COTIDIANAS}

Al momento de su extrañamiento vivían en el colegio veintidós padres, de los cuales tres estaban ausentes el día que se ejecutó la orden, por participar de la administración de las haciendas Vilcahuaura y Humaya. Del total, siete eran sacerdotes profesos de cuarto voto, seis eran padres escolares, cinco hermanos coadjutores y cuatro hermanos donados. ${ }^{27}$ Más del ochenta por ciento de los padres eran naturales del virreinato, incluyendo al rector, originario de Lima. Entre los sacerdotes de cuarto voto había uno solo que era peninsular. Por lo menos, en lo que respecta a este Colegio del Cercado la criollización de sus miembros, en la segunda mitad del siglo dieciocho, había alcanzado niveles extraordinarios. Con todo,

27 ANHCh, Jesuitas de América, vol. 409, cuaderno 1, ff. 12-16. Los sacerdotes eran: el padre Ignacio Romero, a la sazón, rector del colegio, natural de Lima; el padre Manuel Matienzo, natural de Chile; el padre Juan Manuel Balmaceda, natural de La Rioja, España; el padre Alejo de Salas, procurador de esta casa, natural del Cuzco; el padre Juan Lino Pérez, de Huamanga; el padre Eusebio Irarrázabal, de Piura; y el padre Manuel de Pro, que era de Lima. Los padres escolares eran: Francisco Berenguel, natural de España; Pablo Vergara, natural de Lima; Sebastián Zorrilla, de Huancavelica; Pedro Ugalde, de Cochabamba; Pedro Rojo, de España; y Luis Peña y Lillo, administrador de las haciendas de Vilcahuaura y Humaya, natural de Lima. Los hermanos coadjutores eran: Fernando Villegas, de Lima; Mauricio Pérez, de Lima; Matías Sánchez, de Moyobamba; y Eugenio Martínez, de España; a ellos se suma el hermano «escolero» de votos simples Francisco Migues, natural de España. Los hermanos donados eran: Pedro Quispe, de la ciudad de La Paz; Diego Carrión, de Lima; Alejo Solórzano, del Cusco y Tomás Sánchez, de Potosí. A todos ellos debe agregarse el padre Juan Joseph Cortés, natural de Trujillo, que, debido a su demencia, no residía en el colegio. 
esas cifras deben ponderarse considerando las peculiaridades que presentaba la orientación del colegio. Este siempre estuvo asociado al proceso de evangelizar a los indios. Fue un centro en el que el aprendizaje de la lengua quechua constituía una actividad importante. Desde el siglo XVI padres con espíritu misionero iban allí a aprender la lengua de los indios. Y, como lo reconocían las propias autoridades provinciales, a los padres criollos se les daba con más facilidad el aprendizaje de ellas.

Esos padres, ¿cómo distribuían su tiempo diario en el colegio? La jornada se extendía entre las cuatro y treinta de la mañana y las nueve y treinta de la noche. Eran despertados al toque de campana, seguido del paso, aposento por aposento, de un hermano que daba luz en ellos para que se levantaran. A las cinco, todos los padres de la tercera probación y los hermanos coadjutores, debían estar en la capilla interior para dedicar una hora a la oración. Los padres antiguos podían cumplir con esta obligación en sus habitaciones. Se le destinaba a la oración muchas horas. Antes de la once de la mañana debían hacer examen de conciencia durante quince minutos. En tarde, después del descanso posterior a la comida, la comunidad se dirigía a la capilla a rezar las letanías de los santos y las que se decían «por los felices sucesos de nuestro católico monarca». A las cinco de la tarde, en la capilla, se rezaba el rosario, durante media hora, para luego tener otra media hora de lección espiritual, previa a la oración que se seguía hasta las siete de la tarde. Antes de acostarse debían dedicar un tiempo a ver los puntos para la meditación del día siguiente y luego, en la capilla, realizaban examen de conciencia durante quince minutos, para luego retirarse a sus habitaciones. La oración que practicaban correspondía a la que había perfilado la Compañía desde fines del siglo XVI y que pretendía conciliar la contemplación con la acción. Esto se expresaba en la complementariedad que se buscaba entre las horas dedicadas a la oración y el trabajo apostólico y el intelectual. Pero, además, el tipo de oración que practicaban respondía a una espiritualidad que valoraba la me- 
ditación y la mortificación, como necesarias para llegar a la unión con Dios. A eso se agregaban los ejercicios de San Ignacio, que hacían anualmente los padres antiguos y los que realizaban en su último año los de la tercera probación por espacio de treinta días, en tres tiempos: al principio, al medio y al finalizar el año.

En su testimonio sobre el régimen interior, el padre procurador no menciona la ingesta, por la comunidad, de un alimento ligero en las primeras horas de la mañana. De acuerdo con su declaración, después de la oración en la capilla, a las seis de la mañana, los padres se dirigían a la iglesia a decir sus misas en el altar mayor y los más antiguos iban a confesar en los confesionarios del templo, y los tercerones hacían lo propio con los hombres en la sacristía. En los días ordinarios, estos últimos dedicaban parte de la mañana a instruirse en el ceremonial de la misa, a aprender la lengua general de los indios, para predicarles y confesarlos, y a estudiar materias de moral. Aquí encontramos otro aspecto significativo en relación con las actividades de los padres del colegio. Junto a la administración de los sacramentos de la eucaristía y de la penitencia, se enfatizó la preparación en teología moral y en la casuística que esa materia generaba. Así, al estudio que realizaban los padres de la tercera probación, todos los martes en la noche, en reunión de comunidad, se añadía la resolución de casos morales, asignados previamente, con la presencia del padre prefecto.

A las once de la mañana los padres se dirigían al refectorio a comer. A esa actividad, las vísperas de festivos, todos iban preparados a tomar disciplinas en «reverencia de la solemnidad del día siguiente»; y, en los días ordinarios, algunos, llevados de su afán de mortificación, comían bajo las mesas y otros besaban los pies de sus compañeros. Estas eran las únicas referencias que figuran en el régimen interior respecto a mortificaciones públicas que practicaban los padres. Después de la comida, hasta las doce y treinta, se juntaban en la quiete a conversar. Concluida la recreación se trasladaban a la capilla interior a rezar las letanías de los santos. De ahí 
se iban a sus dormitorios a descansar y uno de los tercerones se dirigía a la puerta falsa a repartir comida a los pobres, a la vez que los hacía rezar y luego les explicaba algún aspecto de la doctrina. En las tardes, a partir de las dos, en vísperas de festividad, los padres antiguos iban a confesar a los monasterios y los escolares se dirigían a los hospitales a confesar y predicar a los enfermos. Los días ordinarios los padres antiguos se dedicaban a preparar sus sermones y a recibir confesiones, que nunca faltaban, mientras los tercerones se dedicaban a estudiar y a preparar exposiciones hasta las cinco de la tarde, en que todos, como se ha indicado, debían dirigirse a la capilla a rezar el rosario y luego a otras actividades espirituales. A las siete y treinta se pasaba al refectorio a cenar y, seguidamente, tenían hasta las nueve para ir a la quiete a conversar. Se retiraban a sus aposentos a las nueve y treinta, después de un tiempo dedicado a la meditación $\mathrm{y}$ al examen de conciencia.

\section{La biblioteca. Su tamaño}

El inventario de la biblioteca del colegio se realizó desde el 15 al 20 de septiembre. Durante el procedimiento estuvo presente el procurador del colegio, padre Alejo Salas. Los libros no solo estaban depositados en la biblioteca, sino también, un número importante, se encontraba en los aposentos de algunos padres. Al parecer esta era una práctica abusiva que, con frecuencia, se daba en los institutos de la provincia peruana de la Compañía. En el caso del Colegio de San Pablo de Lima, los libros en los aposentos de los padres constituían verdaderas bibliotecas privadas, al punto que al momento de la expulsión sumaban una cantidad similar a los depositados en la biblioteca (Martín, 1968, pp. 81-85; Guibovich, 2014). En el caso del Colegio del Cercado no se llegaba a ese extremo, pero también su número era importante, pues alcanzaba al sesenta por ciento, aunque aquí pudo existir un posible atenuante: la habitación 
destinada a librería, a la vista del plano del colegio, era de tamaño reducido. Un total de quince padres mantenían libros en sus habitaciones, pero siete de ellos guardaban muy pocos, menos de diez cada uno; aunque el resto tenía cantidades significativas, como el padre Joseph Pérez Bermejo, fallecido hacía poco y que había sido el cura de la parroquia, el cual poseía en su habitación setecientos ochenta y cinco volúmenes. ${ }^{28}$

En la elaboración del inventario, los encargados se atuvieron a las fórmulas habituales utilizadas al respecto, lo que implicaba anotar uno por uno los libros, con una escueta referencia, incompleta, ya sea al autor, al título o la materia, al tiempo que se precisaba el número de volúmenes que tenía cada obra. ${ }^{29} \mathrm{El}$ resultado de esa operación mostró que la biblioteca del colegio contaba con 4,823 volúmenes, que corresponderían aproximadamente a unos 3,300 títulos. ${ }^{30}$ Esa cantidad de volúmenes era significativamente inferior a la que tenía la biblioteca del Colegio San Pablo que, en el siglo XVIII, llegaba a los 9,224 (Guibovich, 2014). Con todo, este era el colegio más importante de la provincia y el del Cercado, durante bastantes años, no pasó de ser solo una residencia. Si se

28 ANHCh, Jesuitas de América, vol. 409, Cuaderno 1, ff. 57v-80r. El padre Manuel Pro, tenía 384 (ff. 34v-38v); el padre Lino Pérez, 223 (ff. 74v-82v); el rector Ignacio Romero, 364 (ff. 85v-95r); el padre Manuel Matienzo, 253 (ff. 95v-100r) y en la habitación de la procuraduría habían 252 (ff. 34v-38v).

29 La biblioteca tenía un catálogo, que no fue utilizado para la realización del inventario. Era un libro manuscrito, en que «estaban por abecedario los libros contenidos en esta biblioteca, así por nombres como por sobre nombres», ANHCh, Jesuitas de América, vol. 409, cuaderno 1, f. 153r.

30 Esta última cifra es una estimación y se obtuvo de hacer un cálculo aproximado del promedio de títulos por página del inventario, que fue multiplicado por el total de las páginas que tiene dicho inventario. Con todo, en el extracto o resumen final del inventario del conjunto de los bienes del colegio se indica que el total de libros impresos era de 5,044. La diferencia se explica porque, después del inventario, se encontraron libros detrás de las hileras de los estantes y rincones de los aposentos y de la biblioteca, ANHCh, Fondo Jesuitas de América vol. 410, ff. 66,108 . 
consideran esos antecedentes, la biblioteca del Cercado resulta de un gran tamaño. Era equivalente a la biblioteca del noviciado de San Antonio Abad que, según el inventario realizado también al momento de la expulsión, tenía 4,961 volúmenes y 3,563 títulos. ${ }^{31}$ Y contaba con muchos más, por cierto, que la modesta biblioteca del colegio de hijos de caciques San Borja del Cusco, que poseía doscientos cincuenta y siete volúmenes (Alaperrine-Bouyer, 2005, p. 168). ¿Qué explica el tamaño de la biblioteca del Cercado? A la vista de este último caso, la cantidad de libros del Colegio del Cercado no parece estar asociada al Colegio del Príncipe. El establecimiento en ese recinto de la tercera probación sin duda justifica la formación de una biblioteca importante. Además, servía de lugar de formación de aquellos que deseaban o requerían aprender la lengua quechua. Tampoco se puede olvidar que durante algunos años funcionó allí el noviciado y, por último, también está el hecho de que desde muy temprano fue vista por diversos padres mayores como lugar de retiro para preparar libros o para descansar en la etapa final de la vida. ${ }^{32}$

31 Jesuitas del Perú (s/f) (https:/ /archivo.jesuitas.pe/historia-la-supresion-y-expulsion/, acceso: 10.I.2021).

32 MP (III, p. 573, carta de Baltazar Piñas al padre Claudio Aquaviva, del 15 de marzo de 1585 , en que se refiere a su estadía en esa residencia). Sobre el aprendizaje de la lengua en ella, ya en el siglo XVI, carta de José de Acosta, provincial, al general Everardo Mercuriano, del 11 de abril de 1579. También actas de la tercera congregación provincial de 1582, en MP (III, pp. 204, 616). El padre Diego Martínez, en la etapa final de su vida, estuvo viviendo en el Colegio del Cercado, al igual que el padre Vasco de Contreras, que permaneció allí durante doce años, donde falleció en 1694, ver Torres Saldamando (1882, pp. 52, 309). En 1606, el exprovincial Juan Sebastián de la Parra solicitó autorización al general para retirarse a la residencia del Cercado, en donde es probable que concluyera su libro sobre el Estado clericaly sacerdotal, véase Millar Carvacho (2020). 


\section{La biblioteca. Temáticas PREdominantes}

No es este el lugar para efectuar un análisis detallado de ella. En el apartado que sigue solo nos limitaremos a señalar los aspectos que, a nuestro juicio, tienen mayor significación. En primer lugar, se aprecia que había libros instrumentales relacionados, ya sea con la enseñanza que se impartía en la escuela para hijos de caciques, como textos de aritmética y de gramática castellana, o con el aprendizaje de la lengua quechua que se efectuaba en el colegio. Entre los primeros estaba la Arithmetica Práctica del padre Padilla y la Aritmética universal del jesuita José Zaragoza, que se encontraban en el aposento del hermano coadjutor Mauricio Pérez. Respecto a la lengua de los indios había varios ejemplares del Arte de la lengua quechua y un Arte de la lengua aymara. La literatura profana era escasa y estaba representada por El Quijote de Cervantes, La Arcadia y La Dorotea de Lope de Vega, Del sano consejo y eficaz, auxilio de Calderón de la Barca, las Aventuras de Telémaco de Fenelón, las Obras de Quevedo y las de Baltasar Gracián, el Gurmán Alfarache de Mateo Alemán y poco más. Las obras de historia tenían mayor presencia, sobre todo las referentes a España y territorios americanos y también las de historia eclesiástica. Entre ellas se pueden mencionar los Comentarios de la guerra de España e historia de su rey Phelipe V de Vicente Bacallar, la Historia de México de Antonio de Solís, las Décadas de Antonio de Herrera, la Historia Universal de Bossuet, la Historia universal, sagrada y profana de Claudio Buffier SJ, la Historia eclesiástica del Viejo Testamento de Ignacio Graveson, la Monarquía Indiana de Juan de Torquemada, la Historia del Nuevo Reino de Granada de Lucas Fernández de Piedrahita, la Historia de Yucatán de Fr. Francisco de Ayeta, la Historia de España vindicada de Pedro Peralta y Barnuevo, a las que podrían agregarse varias más. ${ }^{33}$ También se encontraban

33 Entre ellas estarían diversas historias escritas por padres de la Compañía, incluidas aquellas referentes a su propia orden religiosa. 
en esta biblioteca algunas obras de autores de la antigüedad clásica, como Heródoto, Suetonio, Tácito, Cicerón, Ovidio, Virgilio y Plinio. En materia jurídica, había una cantidad limitada de libros, incluidos los de derecho canónico y de colecciones de leyes y de disposiciones varias. Por ejemplo, las Constituciones de la Universidad de Lima, el de Variarum ex jure pontificio de Diego de Covarrubias, la Recopilación de las leyes de Indias, los sinodales de Lima, la Política Indiana de Solórzano Pereira, los concilios limenses, los cánones y constituciones de la Compañía de Jesús, el Bullarium Magnum Romanum y el Sacrosanctum Concilium Tridentinum.

En la biblioteca abundaban los sermonarios relacionados con las conmemoraciones del calendario litúrgico, como la Cuaresma, la Semana Santa, Adviento y las fiestas de la Virgen, o aquellos que eran recopilaciones de los pronunciados por predicadores destacados de la Compañía o de otras religiones o de clérigos. Entre ellos estaban los de José de Barcia SJ, Manuel Nájera SJ, Andrés Mendo SJ, Paolo Segneri SJ, del canónigo Andrés Amaya, de Fr. Juan de San Gabriel O.M, Joannes de Zeita CRM y de Fr. Pedro de Valderrama, entre otros. También se encontraban obras de los padres de la Iglesia, entre los cuales figuraban San Agustín — con La Ciudad de Dios, Meditaciones y Confesiones_-, San Atanasio, San Buenaventura, San Bernardo, San Ambrosio y San Juan Crisóstomo. Por cierto, no faltaba la Suma de Santo Tomás. Una presencia destacada tenía la teología mística y los libros de espiritualidad. Al respecto se encontraban en ella las obras de Santa Teresa de Jesús, de Tomás de Kempis, de Fray Luis de Granada, la Mistica ciudad de Dios de la monja de Agreda, los Opúsculos espirituales de Nicolás Lancicio SJ, la Vita spirituali de Diego Álvarez de Paz SJ, los Tratados espirituales de Juan Eusebio Nieremberg SJ, los Ejercicios espirituales de San Ignacio y varias obras sobre ellos, la Mística Theologia de Fr. Joan Breton y la Guía espiritual y las Meditaciones de nuestra Santa Fe, con la práctica de la oración mental de Luis de la Puente SJ. 
Mayor significación que todos los temas anteriores tenía la teología moral. Abundaban los libros de autores de la Compañía y de otras religiones sobre aspectos tanto generales como casuísticos referentes a esta materia. Así, había por lo menos un manual de moral, otro registrado como Prontuario moral. Estaba la Suma de Teología Moral de Fr. Enrique de Villalobos OFM, la Theologia Moralis de Tomás Tamburini SJ, las Resoluciones Morales del teatino Antonino Diana, la Teología moral de Claudio Lacroix SJ, las Obras morales de Fr. Martín Torrecilla y las Resoluciones morales del RP. Tomás Hurtado, por mencionar algunos. En la parte casuística estaba la Suma de casos de conciencia de Manuel Ambrosio de Filguera CRM, De Poenitentia de Turriano, Perfecto confesory cura de almas de Iván Machado, De Solicitantibus in confesione de Antonio de Sousa, De religiosa disciplina de Josephi Alderete SJ, Aphorismi confessariorum de Emmanuel Sa SJ, y la Práctica del confesionario de Fr. Jaime Corella, entre otros. ¿Qué explica esta presencia temática en la biblioteca del Cercado? Más allá del interés general de la Compañía por las cuestiones morales, es posible que, en este caso, también hubiera influido el contexto en el que desarrollaban su labor los padres de este colegio. Debe tenerse presente que, como hemos visto en las actividades cotidianas, los sacerdotes administraban diariamente el sacramento de la penitencia a los indios del pueblo, colaboraban con la labor del cura párroco. A eso se agregaba el que otros padres salían de allí regularmente a misiones. En suma, el contacto y trabajo de los padres con los indios hacía que, en la labor pastoral, las cuestiones morales afloraran con una frecuencia, intensidad y singularidad posiblemente mayor que en el seno de la sociedad hispana, lo que obligaba a una formación y reflexión especial sobre dichas materias.

Con todo, el aspecto más significativo de esta biblioteca se refiere a la importante presencia de autores de la Compañía, que en parte se evidenciaba en la relación del tema anterior. Pero no se trataba solo de escritores de la orden, sino también de obras institucionales. Figuraban muchos textos normativos e informativos, 
como las mencionadas constituciones, las reglas de la Compañía, el Canonum societatis Iesu, la Ratio Studiorum, Annuae litterae, Canonum congregationum Societatis, Index decretorun Societatis e Instructiones ad Provintiales. También estaban presentes numerosos autores ajenos a la Compañía con temas que ella valoraba, como los referentes a espiritualidad, teología moral (probabilismo) o a determinados santos, santa Rosa de Lima y Francisco Solano, entre ellos. Pero lo que más llama la atención es la lista impresionante de autores de la Compañía, de las más diversas nacionalidades y con los temas más diversos. Había varias obras sobre San Ignacio, sin considerar los Ejercicios Espirituales, que se referían a su vida o a su beatificación, alguna de autor externo a la Compañía. También se encontraban biografías sobre los demás santos jesuitas: San Estanislao de Koska y San Francisco Xavier, de quien además había una obra en dos volúmenes con cartas. Asimismo, estaban algunas vidas de hombres virtuosos de la orden, como la de los padres Juan de Ugarte, Joseph Vidal, Antonio Baldinucci y Francisco del Castillo. En la nómina, no exhaustiva, de autores jesuitas presentes se encontraban: Eusebio Nieremberg, Manuel Nájera, Andrés Mendo, Antonio Vieria, Paolo Segneri, Juan Martínez de la Parra, Cristóbal Gómez, Jerónimo de Guevara, Diego de Baeza, Antonio de Escobar y Mendoza, Diego de Avendaño, Diego de Celada, Bernardo de Alderete, Antonio Rubio, el Hermano Bufembaun, Gabrielem Hevenesi, Joannis Lugo, Francisco Suárez, Daniel Pawlowski, Cornelio a Lapide, Luis de la Puente, Joanne Baptista Poza, Jacob Tirino, Paul Sherlock, Tomás Muniesa, Alonso Rodríguez, Juan José Villavicencio, Jacinto Barrasa, Francisco Javier Salduendo y Philippe Alegamite. ${ }^{34}$

34 A esa lista y a los autores de teología moral y espiritualidad ya mencionados, podemos añadir a: Philippe Pererii, Daniel Barthole, José María Galluci, Nicolás Causino, Pedro Labbde, Baptista Masculo, Juan Pérez Menacho, Paulo Bombino, Francisco de Salazar, Nicolás Lancicio, Antonio Moreno, Francisco de la Torre, Tomás de Villacastín, Roberto Belarmino, Lorenzo Ortiz, Pedro de Calatayud, Francisco Garau, Guillermo Daubenton, Rodrigo de Valdés, Pedro 
Esa muy importante presencia de autores de la Compañía en la biblioteca del colegio respondía a una política de la orden, ${ }^{35}$ que buscaba alinear a sus miembros en torno a ideales, modelos, planteamientos doctrinarios y teológicos. Toda obra escrita por un padre de la Compañía era sometida a un proceso de revisión y censura, lo que permitía mantener una identidad que la afianzaba y fortalecía institucionalmente. Los libros sobre santos que estaban en esta biblioteca indicaban con claridad los modelos de santidad que a la orden le interesaba promover. Allí, como hemos visto, estaban las vidas de los santos y hombres virtuosos de la Compañía, pero también de aquellos otros con los que se identificaba por los valores que transmitían. ${ }^{36}$ Las vidas escritas sobre sus miembros también tenían un objetivo propagandístico, al buscar posicionar a la orden en el mundo católico, a la vez que contribuían a configurar su imagen y a reafirmar su identidad, al igual que sucedía con los libros

de Ribaneyra, Joseph Buendía, Juan José Salazar, Antonio Franc, Pedro de Torres, Pedro Murillo, Pablo José de Arriaga, Juan Bautista Roza, Juan de Alloza, Francisco Alonso de Malpartida, Fulvio Androtio, Joseph Aguilar, Francisco de Gerónimo, Leonardo Peñafiel, Enrique Engelgrave, Juan Azor, Paulo Layman, Teófilo Raynaud, Juan Martínez de Ripalda, Iacobo Saliano, Jean Boland, José Juvencio, Juan de Mariana, Felipe Alegambre y Fermín de Irisarri. Llama la atención que en esa lista tan extensa y que contiene numerosos autores de la provincia peruana, no figuren los padres José de Acosta, ni Juan Sebastián de la Parra.

35 En los diferentes colegios se daba una situación parecida en cuanto a la presencia de autores de la orden. Para el Colegio del Cusco así lo hace notar Guibovich (2014). También esto se aprecia en la biblioteca del Colegio de Córdoba, estudiada, entre otros, por Page (2000, pp. 18-20). Algo similar se puede notar en la biblioteca del Colegio de San Luis de Potosí a la vista de un inventario parcial de ella, véase García Aguilar (2016). Para el caso de colegios en España, se puede mencionar a la biblioteca del Colegio de San Esteban de Murcia que, al momento de la expulsión, tenía 3,781 títulos y de un total de 860 autores, 365 eran jesuitas, es decir, el cuarenta y dos por ciento, ver Játiva Miralles (2007, pp. 260-261, 269).

36 Al respecto, se pueden mencionar a Santa Rosa, a Mariana de Jesús, a Sebastián de Aparicio, Toribio de Mogrovejo, San Francisco de Asís, San Antonio de San Pedro, Francisco Solano, San Joseph y San Joaquín. 
que referían la historia de la Compañía (García Cárcel, 2010, p. 17). Con las numerosas obras referentes al marco institucional de la orden, a su historia y a la espiritualidad que promovía, se buscaba que sus miembros se impregnaran de lo que significaba ser jesuita y se identificaran con el ideario común que postulaba. Las bibliotecas que existían en todos los colegios respondían a un mandato que se encontraba en la normas fundacionales de la Compañía y en la Ratio Studiorum (Betrán, 2010, p. 26; Martín, 1968, pp. 75, 77) y no solo estaban pensadas en función de los estudiantes, sino sobre todo en la creación intelectual de los padres, quienes con sus obras contribuían a desarrollar los aspectos ya señalados y también ayudaban en su lucha contra la herejía, y a expresar la visión que la orden tenía del mundo (Betrán, 2010, p. 75).

\section{RETABLOS, IMÁGENES Y DEVOCIONES}

Los retablos e imágenes que se encuentran al interior de los templos transmiten determinados mensajes y modelos de vida que se quiere hacer llegar a los fieles. En lo que correspondía a la iglesia del curato, que satisfacía las necesidades espirituales de los indios del poblado, el elemento central, el que convocaba de manera preferente la atención de los fieles y sintetizaba el mensaje principal que pretendía transmitirse, se encontraba en el altar mayor. Con las imágenes, piezas y decoración se pretendía llamar la atención de los asistentes y sensibilizarlos respecto al significado de la representación. Pues bien, el altar mayor se componía de un gran retablo, dorado, de dos cuerpos, con un frontal de madera, también dorado y «charolado», con cuatro espejos en los lados. En el primer cuerpo había dos lienzos. En uno se representaba a la Virgen con San Francisco Xavier y en el otro a este santo bautizando a los gentiles. Ambas imágenes son muy elocuentes. Representan el gran objetivo que tiene la presencia de la Compañía de Jesús en ese poblado: la 
evangelización de los indios, simbolizada por la figura del misionero modélico, el apóstol de las Indias orientales e hijo dilecto de la orden y santo de la Iglesia universal en reconocimiento de su empresa misionera. La primera imagen lo muestra junto a la Virgen, a la que invocaba al realizar su labor evangelizadora (García, 1672, p. 50), y la segunda mostraba el éxito de su prédica, expresada en el bautismo, es decir, en la incorporación a la fe cristiana de aquellos que no la conocían.

En el otro cuerpo del altar mayor había un gran lienzo de la Virgen del Pilar con el apóstol Santiago, flanqueado por los de San Vicente Ferrer y Santa Rosa. La representación de la Virgen y el apóstol hacía referencia a la génesis del proceso evangelizador de España, que se gestó en la aparición de María, aún sobre la tierra, al discípulo de Cristo, a orillas del Ebro, para que persistiera en la cristianización de esas tierras (Ojeda, 1616, p. 38). Vemos aquí nuevamente el tema de la conversión de los pueblos infieles, en una escena muy cara a los miembros españoles de la Compañía, que se identificaban con esa imagen, que la asociaban con el vínculo especial de España con la Inmaculada. Se reafirmaba el simbolismo de la presencia de la imagen del apóstol en el altar mayor, al considerar que el pueblo y la iglesia se denominaban Santiago. ${ }^{37} \mathrm{La}$ presencia, junto a aquel lienzo, de otro en que se representaba a San Vicente Ferrer, se ajustaba a la idea predominante del conjunto: la evangelización, que en este caso se expresaba en este santo, célebre predicador contra los herejes e infieles y a favor de una conversión general al cristianismo. A eso se sumaba el que padres de la Compañía lo consideraban un defensor de la Inmaculada Concepción (Pineda, 1615, p. 9). Por último, el lienzo de Santa Rosa, que cerraba

37 Le pusieron ese nombre por ser el día de Santiago cuando se dijo allí la primera misa (MP, I, p. 416). En la sala de la escuela de los hijos de caciques había un lienzo de la Virgen, que tenía a un lado al apóstol Santiago y en el otro al niño Jesús. ANHCh, Jesuitas de América, vol. 410, f. 115 r. 
el conjunto, representaba, al igual que el de San Francisco Javier bautizando, el éxito de la cristianización del Nuevo Mundo, que había dado frutos tan admirables como el de la virgen limeña. Las representaciones en el altar mayor se completaban con las imágenes de bulto, junto al sagrario, del niño Jesús y de la Virgen del Pilar, a los que se agregaban, en los extremos, las imágenes de San Ignacio y San Francisco Xavier.

Además, a los lados de la mesa del altar mayor y también al costado del depósito de las sagradas formas y a ambos lados del sagrario, en diversos nichos, se encontraban depositadas numerosas reliquias, muchas de ellas con la indicación de a quien o a quienes pertenecían. Figuraban huesos de las Once mil Vírgenes, de Santa Úrsula, de San Mauricio, de los mártires de Tréveris, de San Vitorino, San Justo, San Esteban, Santa María Egipciaca, Santa Polonia, San Isidro, San Timoteo, San Tebeorum, San Jorge y Santo Domingo mártir, San Blas y Santa Gertrudis, entre los que aparecían con identificación. ¿Cómo se explica la presencia de un número tan importante de reliquias en el lugar más prominente de la iglesia parroquial? Las reliquias, en cuanto restos sagrados, expresiones de la entrega de una vida por la fe verdadera, cumplían la función de sacralizar el templo y también el poblado en el que este se asentaba (Fabre, 2011, p. 217; Castelnau-L'Estoile, 2011, p. 225; Coello de la Rosa, 2018, pp. 558-559; Borja, 2008, pp. 129-141), lo cual era muy significativo considerando que se trataba de un pueblo de indios; ayudarían a la evangelización al sustituir a los ídolos (Borja, 2008, p. 140). El auge que experimentó el culto a las reliquias a raíz del redescubrimiento de las catacumbas en Roma (Fabre, 2011, p. 208), asociado a su confirmación por el Concilio de Trento y al movimiento contrarreformista en su enfrentamiento con la herejía, hicieron que se vieran como un símbolo en esa lucha y en el triunfo frente a los herejes. En América, junto a las cualidades típicas asignadas, incluidas las taumatúrgicas, además se les consideró como instrumentos para alcanzar el éxito ante la idolatría, la derrota del 
demonio (Fabre, 2011, pp. 212, 215; Coello de la Rosa, 2018, p. 557). Los jesuitas, en Lima, participaron activamente en la represión de la idolatría que se desarrolló en la primera mitad del siglo XVII. Pero, lo que ocurre con las reliquias en la parroquia del Cercado responde a una política de la Compañía, que la llevó a realizar un incesante traslado de ellas desde Europa a América (Castelnau-L'Estoile, 2011, p. 226); y en los colegios, en ambos mundos, su presencia fue muy importante. ${ }^{38}$ Esta particularidad que muestra la institución en esta materia posiblemente esté relacionada con el hecho de que fuese una orden nueva, que requería integrarse a la historia del cristianismo. Las reliquias de los mártires, por representar el espíritu de los santos antiguos, les permitían sentirse parte de la construcción de aquella y del triunfo de la fe.

Los altares laterales, con sus respectivas advocaciones, y lienzos e imágenes en lugares prominentes del templo, indicaban muy bien cuáles eran las devociones que, de preferencia, al colegio le interesaba promover entre los indios. Así, en el presbiterio había un cuadro de la coronación de la Virgen por la Santísima Trinidad, con San Ignacio y San Francisco de Asís a los pies. El tema de esta obra era muy significativo para la provincia peruana, pues hay constancia de que el hermano Bernardo Bitti habría pintado cuatro lienzos de él. ${ }^{39}$ Además, había otro cuadro con ese tema en la portería del Colegio de San Pablo, atribuido al pintor italiano Angelino Medoro (Solórzano González, 2012, p. 75). Llama la atención que en la

38 Referencias sobre las reliquias en la iglesia del Colegio San Pablo de Lima en Mujica Pinilla (2018, pp. 147-149). Sobre la distribución de reliquias en la provincia peruana de la Compañía, ver Valenzuela Márquez (2006, p. 58).

39 Uno para el retablo mayor de la iglesia del Colegio de San Pablo, otro para la doctrina de Juli, un tercero para la iglesia de la Compañía del Cusco y, al parecer, un cuarto para la residencia de Potosí. Se ha planteado que los cuadros de la Coronación de la Virgen servían para facilitar las meditaciones en los Ejercicios de San Ignacio, cuya segunda semana estaba dedica a la contemplación de la Santísima Trinidad, ver Solórzano Gonzales (2012, pp. 29-30, 64). 
composición del cuadro del Colegio del Cercado aparezcan, en la parte inferior, las dos figuras mencionadas, que no se encuentran en ninguno de los cuadros anteriores (Solórzano González, 2012, pp. 32-34). La presencia de ambos muestra la particular devoción que manifestaron por la Virgen, y también el que las órdenes religiosas que fundaron la tuvieran como centro de su piedad (Alloza, 1655, pp. 465-481). Para los jesuitas, la imagen de la Reina de los Cielos, a cuya coronación asistían a través de San Ignacio, era un elemento central del discurso evangelizador (Valenzuela Márquez, 2006, pp. 47-48; Polia, 1996, p. 236).

Los altares laterales, por el lado del evangelio, estaban dedicados a la Inmaculada Concepción (además tenía una capilla), a San Pedro, a Santa Ana y San Joaquín y al Ángel de la Guarda; por el lado de la epístola, a la Virgen de la Candelaria, a San José y a Santa Rosa. Más allá de la promoción de sus santos (aparte de las representaciones indicadas había una capilla dedicada a San Ignacio), a la Compañía le interesaba impulsar el culto a la Virgen como tema prioritario, en sus advocaciones de la Inmaculada, del Pilar y de la Candelaria. A la segunda ya nos hemos referido y destacado el papel que se le asignaba en el proceso de cristianización de España. La Candelaria o Copacabana era la devoción que conciliaba la cultura indígena con el cristianismo y, por lo tanto, figura central del proceso evangelizador, a lo que se agregaba la necesidad de acentuar su presencia en el Cercado después de los conflictos con Mogrovejo. Los jesuitas no solo la consideraron importante en Lima, sino también impulsaron su culto en territorios de misiones, como los del Paraguay y Chiloé. La identificación de la Compañía con la defensa de la doctrina de la Inmaculada Concepción se manifestó casi desde sus primeros tiempos y se transformó, junto a los franciscanos, en la orden que con más fervor luchaba por la declaración del dogma. Promovía su devoción a través de todo el mundo católico y en Perú asumió esa labor con especial vitalidad, para contribuir a que se concretara aquella proclamación (Millar Carvacho, en prensa). 
Un vínculo directo del compromiso de los jesuitas con el culto a la Virgen se aprecia en la promoción que se hace de la devoción a San José y a los padres de María. Respecto a Santa Rosa, ya hemos mencionado el aprecio especial que la Compañía siempre mantuvo por ella, posiblemente asociado al hecho de que algunos padres habían sido sus confesores durante la etapa final de su vida (Mujica Pinilla, 2005; 2018, pp. 196-197). El que se dedicara un altar específico al Ángel de la Guarda resulta coherente con la devoción que, desde su etapa fundacional, le mostraron los miembros de la Compañía, al punto de transformarse en los promotores más importantes de su culto (Aicardo, 1920, p. 560). Por último, no deja de ser significativo que, al lado del baptisterio, hubiese un lienzo de santo Toribio de Mogrovejo, no obstante la controversia que con él tuvo la Compañía, justamente por la doctrina del Cercado (Coello de la Rosa, 2000; Nieto Vélez, 2009).

Las devociones que se trataron de promover entre los indios encuentran un indicador de receptividad en las cofradías que se fundaron en la parroquia, en su pervivencia y en los obsequios que sus cófrades hicieron a sus imágenes. Un total de seis cofradías existían al momento de la expulsión de la Compañía: las del Santísimo, San Pedro, San Joseph, Santiago, de las Ánimas y de la Candelaria. Cuatro de ellas guardan correspondencia con la promoción de sus cultos que reflejan los altares e imágenes existentes en el templo. ${ }^{40}$ Según el inventario realizado en cumplimiento del decreto de extrañamiento, todas las cofradías disponían de objetos de valor, con los que generalmente adornaban las imágenes. Así, por ejemplo, las piezas de plata de cinco cofradías que estaban en la habitación del cura, más las que entregaron los mayordomos, pesaron en bruto

40 Si se considera la cofradía del Santísimo Sacramento, cinco serían las que responden a una promoción que se origina en la orden. La Compañía de Jesús difundió la adoración al Santísimo o ejercicio de las cuarenta horas, como reacción a las profanaciones que experimentaba la Eucaristía en los países protestantes, en Campos y Fernández de Sevilla (2014, p. 18). 
trescientos setenta y tres marcos y dos onzas. En unos cajones de la iglesia se encontraron alhajas de las cofradías que pesaron cincuenta y un marcos. En la sacristía del colegio se inventariaron alhajas pertenecientes a la cofradía del Santísimo por quinientos marcos de plata. En el mismo lugar había adornos con perlas, plata y oro pertenecientes a la imagen de la Candelaria con el niño. Las alhajas pertenecientes a esa cofradía que estaban en el baptisterio pesaron cuarenta y seis marcos de plata. También se encontraron diversas piezas pertenecientes a la cofradía de las Ánimas del Purgatorio, algunas de las cuales pesaron trece marcos de plata. En suma, el inventario reflejó que las cofradías poseían numerosas alhajas y adornos con telas finas y valiosas, lo que muestra que los fieles se identificaron con esas devociones y les hicieron importantes obsequios. Ese compromiso de los indios del Cercado con los bienes de sus cofradías se evidenció en la demanda que hicieron para recuperar, con posterioridad al inventario, una serie de alhajas y objetos sagrados que estimaban pertenecerles, lo que lograron por considerarse que ello serviría de «consuelo de su devoción y para decencia y culto de esta parroquia». ${ }^{41}$

\section{Patrimonio y finanzas}

La comisión designada por el gobierno inventarió todos los objetos existentes en las instalaciones del colegio, factibles de ser registrados, incluyendo los de la iglesia. Así, por ejemplo, en la escuela de los caciques se inventariaron diez bancas, dos taburetes, una mesa con sus cajones, entre otros objetos; también se dejó constancia, con sus nombres y edades, de los seis esclavos que poseía el colegio; en el inventario no figuraban los esclavos que poseían las distintas haciendas, los que se registraron al inventariar cada una de

41 ANHCh, Jesuitas de América, vol. 410, cuaderno 3º f. 117. 
ellas (Tardieu, 2003, p. 66); ${ }^{42}$ tampoco se hacía mención a la cárcel de Santa Cruz para los hechiceros, ni al hospital que funcionó en el Cercado, aunque se dejó testimonio de unas cuentas que existían «del antiguo hospital de San Blas que hubo en este pueblo». Los únicos bienes que se tasaron fueron las alhajas que había en las distintas instalaciones del colegio y que correspondían mayoritariamente a ornamentos de imágenes religiosas y objetos del culto. Las alhajas de plata que pertenecían a la parroquia y a las cofradías se estimaron en un peso neto de 875 marcos, y las que correspondían a la iglesia y a la sacristía del colegio en $873 .{ }^{43}$ A esas cantidades se agregaron otros 50 marcos, provenientes de alhajas que estaban en dependencias del colegio y en la capilla interior. También quedó constancia de 2,856 pesos 7.5 reales en dinero en efectivo, que se encontraron en las habitaciones del rector, del procurador y de otros padres. ${ }^{44}$

Durante los años en que el Cercado fue solo una doctrina se financió con un aporte de 500 pesos ensayados anuales, ${ }^{45}$ que, me-

42 La hacienda Vilcahuaura poseía 206 esclavos entre hombres y mujeres; La Humaya, 176; San Borja, 14. El autor agrega otra hacienda de propiedad del colegio, la de N. Sra. de la Candelaria, con 134 esclavos, que no está considerada en el inventario del colegio. Tardieu (2013) no se refirió a los esclavos «que servían en el ministerio de los colegios», entre los que se encontraban los seis que hemos mencionado.

43 ANHCh. Jesuitas de América, vol. 409, ff. 212v-214v. Los padres, en relación con la iglesia, distinguían entre los bienes de la parroquia y los del colegio. Así, consideraban que el altar mayor con todas sus alhajas pertenecía al colegio, al igual que las dos capillas y altares colaterales, correspondientes a la Inmaculada y a San Ignacio. También, debe recordarse que en el templo existían dos sacristías, la de la parroquia y la del colegio, como se puede apreciar en el plano.

44 ANHCh, Jesuitas de América, vol. 409, f. 17. En un extracto de los inventarios se indica que la plata sellada de la casa sería de 2,286 pesos y que en depósitos habrían 1,318 pesos 5 reales y medio, vol. 410, f. 66r. Aunque la cifra difiere, hay una cierta relación con el dinero encontrado en las habitaciones de algunos padres. La cifra de los depósitos corresponde a dineros que diversas personas dejaron en custodia, del rector principalmente, para cumplir determinados compromisos, ver vol. 409, ff. 17-22.

45 Los 500 pesos ensayados equivalían a 827 pesos de 8 reales. 
diante provisión, estableció el virrey Toledo, a pagar por los encomenderos que tuviesen indios en el pueblo. Hasta mediados del siglo XVIII la parroquia continuaba recibiendo esa cantidad, que se pagaba por la caja general de censos de indios, como lo confirma el virrey conde de Superunda en su memoria de gobierno (Fuentes, 1859, IV, p. 8; Cárdenas Ayaipoma, 1980, p. 39). Cuando a fines del siglo XVI el noviciado se trasladó al Cercado se sustentó con el aporte que hacían los demás colegios de la provincia, porque no tenía rentas propias. ${ }^{46} \mathrm{Si}$ bien es posible que ese aporte desapareciera cuando el noviciado se instaló definitivamente en Lima, algo debió mantenerse para el funcionamiento de la residencia, a la que la parroquia estaba integrada. Al crearse el colegio de hijos de caciques, en 1619, se estableció una asignación por parte de la hacienda real, o para ser más precisos, de la caja de censos de indios, de 600 pesos de 9 reales, más los gastos de alimentación y vestidos de los estudiantes. Como aquel monto estaba destinado a pagar al rector y dos hermanos colaboradores y el primero era al mismo tiempo el cura, por el que recibía el sínodo correspondiente, se redujo aquella partida en 200 pesos, la que volvió a disminuirse en 1662, para dejarse en 225 pesos para financiar un solo hermano por el escaso número de estudiantes (Alaperrine-Bouyer, 2007, p. 90).

El gran cambio en materia financiera se produjo en 1640 con la donación de los cincuenta mil pesos de Clemente Fuentes para la fundación del colegio. Con ese dinero, en 1641, se compró para este colegio, por el provincial Nicolás Mastrillo Durán, la hacienda Vilcahuaura. ${ }^{47} \mathrm{Al}$ momento de la expulsión, el colegio mantenía esa propiedad, que era hacienda de caña e ingenio, y además la hacienda La Humaña, de caña con seis trapiches, sin ingenio; ambas ubicadas en la zona de Huaura; la de San Borja, a una legua del colegio, de

46 MP (V, p. 329, informe del provincial Juan Sebastián de la Parra, 8 de marzo de 1594).

47 ANHCh, Jesuitas de América, vol. 409, cuaderno 2, f. 14 r. 
pan llevar, que estaba arrendada en mil pesos al año y diez burros de alfalfa diaria; una huerta llamada San Rodrigo, a la salida de la ciudad de Lima, que tenía una extensión de 55,872 varas cuadradas (4.6 hectáreas); unos corralones de pastos, conocidos como Aucallama, para las mulas que llevan el azúcar de las dos haciendas; y dos casitas, una en Lima y la otra en el poblado pegada al colegio: a la primera se la conocía como casa de Mena, servía de panadería y estaba arrendada; la segunda se ubicaba frente a la escuela pública del poblado, estaba bastante ruinosa y allí funcionaba la lavandería de los padres del colegio. ${ }^{48}$ Las propiedades rústicas mencionadas, al momento de la expulsión, fueron tasadas en 450,957 pesos (Macera, 1966, p. 8). ${ }^{49}$

El colegio se financiaba con la renta que generaban sus propiedades, algunas explotadas directamente y otras dadas en arriendo. Hasta la fecha de la expulsión los ejercicios financieros anuales se mostraban relativamente equilibrados, con pérdidas o utilidades de entre mil y dos mil por año. Sin embargo, la realidad era no solo más compleja, sino también negativa, debido a que poseía unos pasivos muy altos. Para hacer frente a inversiones, consumo, reparaciones y reconstrucción, sobre todo luego del terremoto de 1746, se endeudaba directamente con particulares o mediante la contratación de censos. A la fecha del inventario, el colegio debía a particulares, por pagos diferidos de productos, un total de 2,268 pesos y tenía censos impuestos sobre las haciendas de dicho colegio por 97,880 pesos, lo que le significaban pagar unos réditos de alrededor de 2,900 pesos anuales. Por otra parte, el colegio también tenía deudas a su favor por un total de 14,435 pesos, muchas por compras de azúcar y aguardiente, aunque podían estar enteramente perdidas, al decir

48 ANHCh, Jesuitas de América, vol. 409, ff. 33v-35r; 161r-164v.

49 Entre las posesiones del Colegio del Cercado, Pablo Macera incluye a la hacienda Carquín, de pan llevar, ubicada en Huara y tasada en 150 pesos, la que no figura en el inventario de 1767. 
del procurador. En suma, de acuerdo con la revisión de los libros de cuentas de la procuraduría, el colegio resultó con un alcance de 85,713 pesos, si bien tenía una capacidad de pago suficiente para hacer frente a los réditos anuales de esa deuda.

\section{Conclusiones}

En 1767, el colegio no parecía mostrar signos de deterioro en sus instalaciones, salvo en las torres de la iglesia, posiblemente secuela, sin restaurar, del terremoto de hacía veintiún años. El estado general que presentaba era satisfactorio y no había muestras de decadencia. Salvo el colegio de caciques, que sí mostraba un declive reflejado en el escaso número de estudiantes, el resto de las actividades parecía estar en buen pie. El número de padres que en él residían era un indicio de ello. El colegio giraba en torno a la actividad evangelizadora. Esto se apreciaba en el trabajo parroquial, a pesar de que, justo en ese momento, no se contaba con cura por su reciente fallecimiento, pero los padres mayores realizaban diariamente una labor apostólica con los indios en el templo. Y en relación con este, las representaciones en los altares e imágenes reflejaban un objetivo evangelizador y el afán por difundir determinadas devociones entre los indios, que eran sus únicos fieles. ${ }^{50}$ Las cofradías se mantenían activas y todos sus mayordomos estuvieron atentos al proceso de ejecución de los inventarios y protestaron cuando estimaron que los bienes de ellas eran incautados. La índole predominante del colegio también se manifestaba en las misiones que con regularidad salían hacia la sierra. El que una de las temáticas que predominaba entre los libros de la biblioteca fuera la teología moral y sobre todo

50 Según la memoria del virrey Superunda (1761) en el Cercado y Lima vivían 2,078 indios. Es de suponer, por lo tanto, que en el poblado había en ese entonces alrededor de 1,800 residentes, ver Fuentes (1859, IV, p. 7). 
la casuística en ese campo, pueden, en cierto sentido, ser asociados al objetivo evangelizador. Tampoco se puede omitir que el colegio era el centro por antonomasia donde se iba a aprender la lengua de los indios, indispensable para la labor misionera. Pero la vitalidad de este instituto también estuvo asociada al hecho de que fuera el establecimiento donde los padres de la provincia realizaban la tercera probación. Eso lo hacía un centro formativo importante que justificaba la existencia de una valiosa biblioteca.

\section{Archivos}

Archivo Nacional Histórico de Chile

Fondo Jesuitas de América, vols. 409-410.

\section{Archivum Romanum Societatis Iesu}

Perú 4.

\section{REFERENCIAS}

Aicardo, José Manuel (1920). Comentarios a las Constituciones de la Compañia de Jesús. Volumen 2. Madrid: Imprenta San Mateo.

Alaperrine-Bouyer, Monique (2005). «La biblioteca del colegio de yngas nobles: San Borja del Cuzco». Histórica, vol. XXIX, núm. 2, pp. 163179.

Alaperrine-Bouyer, Monique (2007). La educación de las elites indígenas en el Perú colonial. Lima: Instituto Francés de Estudios Andinos, Instituto Riva Agüero; Instituto de Estudios Peruanos.

Albó, Xavier (1966). «Jesuitas y culturas indígenas. Perú 1568-1606». América Indígena, vol. XXVI, núm. 3, pp. 251-308. 
Alloza, Juan de (1655). Cielo estrellado de mil y veynte y dos exemplos de María. Paraíso espiritual y tesoro de favores. Madrid: s/e.

Betrán, José Luis (2010). «El bonete y la pluma: la producción impresa de los autores jesuitas españoles durante los siglos XVI y XVII». En: José Luis Betrán (ed.). La Compañía de Jesús y su proyección mediática en el mundo hispánico durante la Edad Moderna. Madrid: Silex ediciones, pp. 23-76.

Borja, Jaime Humberto (2008). «Las reliquias, la ciudad y el cuerpo social. Retórica e imagen jesuítica en el reino de Nueva Granada». En: Perla Chinchilla y Antonella Romano (coords.). Escrituras de la modernidad. Los jesuitas entre cultura retórica y cultura científica. México: Universidad Iberoamericana; L'École des hautes études en sciences sociales.

Campos y Fernández de Sevilla, Javier (2014). «Aproximación al mundo de las cofradías». En: Javier Campos y Fernández de Sevilla (ed.). Catálogo de cofradías del Archivo del Arzobispado de Lima. Madrid: Ediciones Escurialenses.

Cárdenas Ayaipoma, M. (1980). «El pueblo de Santiago. Un Ghetto en Lima Virreynal». Bulletin de l'Institut français d'etudes andines, núm. 9, pp. 19-48.

Castelnau-L'Estoile, Charlotte de (2011). «Compartir las reliquias. Indios Tupíes y jesuitas frente a los huesos de un misionero chamán en el Brasil de inicios del siglo XVII». En: Guillermo Wilde (ed.). Saberes de la conversión. Jesuitas, indígenas e imperios coloniales en las fronteras de la cristiandad. Buenos Aires: Editorial SB, pp. 225-250.

Coвo, Bernabé (1882). Historia de la Fundación de Lima. Lima: Colección de Historiadores del Perú.

Coello de la Rosa, Alexandre (2000). «Patrimonialismo, privilegios políticos e Iglesia en la Lima colonial (1580-1592)». Histórica, vol. XXIV, núm. 2, pp. 259-294. 
Coello de la Rosa, Alexandre (2002). «Resistencia e integración en la Lima colonial: el caso de la reducción de los indios de El Cercado de Lima (1564-1567)». Revista Andina, núm. 35, pp. 111-128.

Coello de la Rosa, Alexandre (2004). «El último asalto: el Arzobispo Toribio de Mogrovejo y los jesuitas de Santiago del Cercado colonial, 1595-1606». Colonial Latin American Historical Review, núm. 13, pp. $1-30$.

Coello de la Rosa, Alexandre (2006). Espacios de exclusión, espacios de poder: el Cercado en Lima colonial (1568-1606). Lima: Instituto de Estudios Peruanos; Pontificia Universidad Católica del Perú.

Coello de la Rosa, Alexandre (2018). «Reliquias globales en el mundo jesuítico (siglos XVI-XVIII)». Hispania Sacra, vol. LXX, pp. 555-568.

Egaña, Antonio (ed.) (1954-1986). Monumenta Peruana. Roma: Monumenta Histórica Soc. Iesu.

Esquilache, Príncipe de (1978). Memoria de gobierno Francisco de Borja y Aragón, principe de Esquilache. En: Lewis Hanke (ed.). Los virreyes españoles en América durante el gobierno de la casa de Austria Perú. Tomo II. Madrid: Real Academia Española.

Estenssoro Fuchs, Juan Carlos (2003). Del paganismo a la santidad. La incorporación de los indios del Perú al catolicismo 1532-1750. Lima: Instituto Riva-Agüero; Instituto Francés de Estudios Andinos.

FABRE, Pierre Antoine (2011). «Reliquias romanas en México: Historia de una migración». En: Guillermo Wilde (ed.). Saberes de la conversión. Jesuitas, indígenas e imperios coloniales en las fronteras de la cristiandad. Buenos Aires: Editorial SB, pp. 207-224.

Fuentes, Manuel Atanasio (1859). Memorias de los virreyes que han gobernado el Perú. Tomo 4. Lima: Librería Central de Felipe Bailly.

García, Francisco (1672). Vida y milagros de San Francisco Xavier, de la Compañia de Jesús. Madrid: Juan García Infanzón. 
García Aguilar, María Idalia (2016). «Entre el olvido y la supervivencia: los libros jesuitas del colegio de San Luis Potosí». Revista de El Colegio de San Luis, Nueva época, año VI, núm. 11, p. 48-105.

García CÁrcel, Ricardo (2010). «Introducción. Los jesuitas y la memoria histórica». En: José Luis Betrán (ed.). La Compañia de Jesús y su proyección mediática en el mundo hispánico durante la Edad Moderna. Madrid: Silex ediciones, pp. 15-22.

Gramatowski, Wiktor (1992). Jesuit Glossary: Guide to understanding the documents. Roma.

Guía de Fondos del Archivo Nacional Histórico (2009). Santiago: Archivo Nacional de Chile.

Guibovich, Pedro (2014). El edificio de letras. Jesuitas, educación y sociedad en el Perú colonial. Lima: Universidad del Pacífico.

Játiva Miralles, María Victoria (2007). La biblioteca de los jesuitas del Colegio de San Esteban de Murcia. Tesis de doctorado. Murcia: Universidad de Murcia.

Jesuitas del Perú (s/f). «Historia. S. XVIII. 5. Supresión y expulsión». Extraído de un artículo de Armando Nieto S. J. Disponible en: https:// archivo.jesuitas.pe/historia-la-supresion-y-expulsion/. Acceso: 10.I.2021.

Macera, Pablo (1966). Instrucciones para el manejo de las haciendas jesuitas del Perú (ss. XVII-XVIII). En: Nueva Coronica, vol. II, fasc. $2^{\circ}$. Lima: Universidad Nacional Mayor de San Marcos.

Martín, Luis (1968). The intellectual conquest of Peru. The Jesuit College of San Pablo, 1568-1767. Nueva York: Fordham University Press.

Mateos, F. (ed.) (1943). Historia General de la Compañia de Jesús en la provincia del Perú. Crónica anónima de 1600. Madrid: Biblioteca «Misionalia Hispánica»; Instituto Fernández de Oviedo. 
Mattos-Cárdenas, Leonardo (2004). Urbanismo Andino e Hispano Americano. Ideas y realizaciones (1530-1830). Lima: Universidad Nacional de Ingeniería.

Mattos-Cárdenas, Leonardo (2016). «El plano inédito de la "casona" de San Marcos y la obra de Cristóbal de Vargas (siglo XVIII). El "Módulo B-A-B" y su recuperación». Devenir, vol. 3, núm. 5, pp. 28-44.

Millar Carvacho, René (ed.) (2020). Identidad jesuita: Juan Sebastián de la Parra (Daroca 1546 - Lima 1622). Su vida escrita por Francisco Figueroa SJ (Sevilla 1592 - Lima 1639). Con colaboración de Magdalena Urrejola Santa María. Lima: Pontificia Universidad Católica de Chile; Universidad Antonio Ruiz de Montoya.

Millar Carvacho, René (en prensa). «Las fiestas a la Inmaculada Concepción celebradas en Lima en 1617: Los jesuitas y Antonio León Pinelo». En: Roma, L'Immaculata Concezione e l'universalismo della Monarchia Cattolica.

Mujica Pinilla, Ramón (2005). Rosa limensis. Mistica, política e iconografía en torno a la patrona de América. México: Fondo de Cultura Económica, Instituto Francés de Estudios Andinos.

Mujica Pinilla, Ramón (2018). «Retablos y devociones para el "Salomón de las Indias": de la máquina barroca al teatro de la memoria». En: Ramón Mujica Pinilla, Luis Eduardo Wuffarden Revilla y Juan Dejo Bendezú (coords.). San Pedro de Lima. Iglesia del antiguo Colegio Máximo de San Pablo. Lima: Banco de Crédito del Perú, pp. 141-204.

Nieto Vélez, Armando (2009). «El conflicto de la doctrina del Cercado (1590-1591)». Revista Peruana de Historia Eclesiástica, núm. 9, pp. $175-188$.

OJEDA, Pedro de (1616). Información eclesiástica en defensa de la Limpia Concepción de la Madre de Dios. Sevilla: Alonso Rodríguez Gamarra.

Page, Carlos A. (2019). «Los planos de los colegios jesuíticos de Lima, Ayacucho y Sucre de la Biblioteca Nacional de Francia». Alteritas, núm. 9, pp. 247-262. 
Pallas, Gerónimo (2006). Missión a las Indias. De Roma a Lima: La "misión a las Indias", 1619 (razón y visión de una peregrinación sin retorno). Estudio y transcripción de José J. Hernández Palomo. Sevilla: Ministerio de Educación y Ciencia; Consejo Superior de Investigaciones Científicas.

PINeda, Juan (1615). Sermón Del Padre Ioan Pineda de la Compañia de Jesús. En el primer Octavario a la Inmaculada Concepción de la Santísima Virgen de Dios. Sevilla: Alonso Rodríguez Gamarra.

Polia, Mario (1996). «Siete cartas inéditas del Archivo Romano de la Compañía de Jesús (1611-1613): huacas, mitos y ritos andinos». Anthropológica, núm. 14, pp. 209-259.

Puente Brunke, José de la (1998). «"Los vasallos se desentrañan por su rey”: notas sobre quejas de curacas en el Perú del siglo XVII». Anuario de Estudios Americanos, tomo LV, núm. 2, pp. 459-473.

Ríos FigueroA, María Esther (2014). «Urbanismo barroco en la Lima virreinal: hacia la recuperación de la Calle de la Amargura», Devenir, vol. 1, núm. 2, pp. 41-58.

Rodríguez, David (2005). «Los jesuitas y su labor evangelizadora en la doctrina de Santiago del Cercado». Investigaciones Sociales, año IX, núm. 15, pp. 133-149.

SAITO, Akira y Claudia Rosas Lauro (eds.) (2017). Reducciones. La concentración forzada de las poblaciones indigenas en el V irreinato del Perú. Lima: Pontificia Universidad Católica del Perú.

San Cristóbal Sebastián, Antonio (2011). Arquitectura virreinal religiosa de Lima. Lima: Universidad Católica Sedes Sapientiae.

Solórzano Gonzales, Mónica (2012). La Coronación de la Virgen por la Santísima Trinidad de Bernardo Bitti en el arte peruano virreinal. Tesis de maestría. Lima: Pontificia Universidad Católica del Perú.

Soto Cárdenas, Alejandro (1953). Misiones Chilenas en los Archivos Europeos. México: Instituto Panamericano de Geografía e Historia. 
TARdieu, Jean-Pierre (2003). «Los esclavos de los jesuitas del Perú en la época de la expulsión (1767)». Caravelle, núm. 81, pp. 61-109.

Torres Saldamando, Enrique (1882). Los antiguos jesuitas del Perú. Lima: Imprenta Liberal.

Valenzuela Márquez, Jaime (2006). «“...que las imágenes son los ydolos de los christianos". Imágenes y reliquias en la cristianización del Perú (1569-1649)». Jahrbuch für Geschichte Lateinamerikas, vol. 43, núm. 1, pp. 41-66.

Vargas Ugarte, Rubén (1963). Historia de la Compañia de Jesús en el Perú. Burgos: Imprenta de Aldecoa.

Fecha de recepción: 11 de enero de 2021. Fecha de evaluación: 11 de mayo de 2021. Fecha de aceptación: 1 de junio de 2021.

Fecha de publicación: 1 de noviembre de 2021. 